\title{
Japon Toplumunda Şükran Olgusu: Dil ve Kültür Bağlamında Bir İnceleme DR.ÖĞR. ÜYESİ LEVENT TOKSÖZ*
}

Öz

Pozitif psikoloji yaklaşımının etkisiyle son yıllarda 'şükran' olgusu üzerine yapılan araştırmaların sayısında artış görülmektedir. Pozitif psikoloji, bireyin olumlu yönlerini ortaya çıarma ve destekleme yoluyla günlük hayatını daha mutlu ve sağlıklı yaşayabilmesini amaçlar. Bu bağlamda şükran olgusu üzerine gerçekleştirilen çalışmalarda minnet duygusunun insan hayatındaki pozitif etkileri açığa çıkarılmıştır. Fakat birçok kültürden farklı olarak Japonya'da şükran durumlarında 'memnuniyet' gibi pozitif duyguların yanı sıra, 'suçluluk' gibi negatif duyguların da meydana geldiği bilinmektedir. $\mathrm{Bu}$ özelliğiyle Japon dili ve kültürü incelenmesi gereken bir örnek olarak karşımıza çıkmaktadır.

$\mathrm{Bu}$ çalışmada, çeşitli alan çalışmaları tanıtılarak Japon insanının şükran olgusuna yönelik bakış açısı irdelenecektir. Japonların sıklıkla deneyimledikleri şükran durumları, söz konusu durumlarda hissettikleri duygular, bu duyguların dilsel yansımaları ve bunun arkasında yatan ahlaki yargılar çalışmanın ana çerçevesini oluşturacaktır.

Anahtar sözcükler: Japonya, Şükran, Hissel Deneyim, Dilsel Yansıma.

\section{THE PHENOMENON OF GRATITUDE IN JAPANESE SOCIETY:}

\section{AN STUDY IN THE CONTEXT OF LANGUAGE AND CULTURE}

Abstract

With the effect of positive psychology approach, there has been an increase in the number of studies on the phenomenon of 'gratitude' in recent years. Positive psychology aims to enable the individual to live his / her daily life happier and healthier by revealing and supporting his / her positive aspects. In this context, the positive effects of gratitude on human life have been revealed in the studies conducted on the phenomenon of gratitude. But unlike many cultures, in Japan, in addition to positive feelings such as 'pleasure' in situations of gratitude; negative feelings such as 'guiltiness' are also known to occur. With this feature, Japanese language and culture emerges as an example to be studied.

\footnotetext{
* Namık Kemal Ün. Fen-Ed. Fak. Doğu Dil. ve Edb. Bölümü. ltoksozku.edu.tr, orcid.org/0000-0003-2212-2976 
In this study, various field studies will be introduced and Japanese people's perspective on the phenomenon of gratitude will be studied. The phenomenon of gratitude that Japanese often experience, the emotions they feel in these situations, the linguistic reflections of these feelings, and the moral judgments behind it will be the main frame of the study.

Keywords: Japan, Gratitude, Sentimental Experience, Linguistic Reflection.

\section{Gíriş}

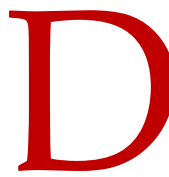
uygu, düşünce ve davranış arsındaki ilişkiyi inceleyerek daha mutlu bir insan hayatının arayışı içinde olan psikoloji bilimi, sürekli bir devinim hâlinde olagelmiştir. Bu durum, alan çalışmalarında hâkim olan temel yaklaşımlarda da etkisini gösterir. Örneğin; İkinci Dünya Savaşı sonrası yapılan çalışmaların büyük çoğunluğu ruh sağlığı bozukluklarının teşhisi ve tedavisine yönelikken, son yıllarda kişinin pozitif yönlerini ortaya çıkarma ve geliştirmeyi amaçlayan 'pozitif psikoloji' yaklaşımının önem kazandığı görülmektedir (Seligman\&Csikszentmihalyi, 2000).

Pozitif psikoloji, bireyin olumlu yönlerini ortaya çıarma ve destekleme yoluyla günlük hayatını daha mutlu ve sağlıklı yaşayabilmesini amaçlar (Luthans,2002). Bu yaklaşımının etkisi ile son yıllarda 'mutluluk', 'memnuniyet', 'sevgi' gibi pozitif duyguları ele alan çalışmalarda artış yaşanmakta; bu duyguların biliş ve davranış üzerindeki etkileri araştırmalara konu olmaktadır (Fredrickson,1998).

Pozitif psikoloji yaklaşımının etkisiyle son yıllarda üzerinde araştırma yapılan konulardan biri de 'şükran' olgusudur. Sözlük anlamı olarak 'iyilik bilme, gönül borcu, minnettarlık' mânasına gelen şükran (TDK, 1998); yurt dışında yapılan çalışmalarda çoğunlukla 'gratitude' kelimesi ile ifade edilir. (Barlet\&DeSteno, 2006; McCullough, Kilpatric, Emmons,\&Larson,2001 vd). Fakat 'gratitude' kavramının Türkçe karşılığı üzerine ülkemizdeki alan yazında kesin bir uzlaşı bulunmamakta, 'şükran' kelimesinin yanı sıra 'minnettarlık', 'şükür' gibi kavramların da birlikte kullanıldığı anlaşılmaktadır (Kardaş\&Yalçın, 2018) . Bu çalışmada 'gratitude' kelimesinin Türkçe karşılığı olarak 'şükran' ifadesi kabul edilmiştir.

Şükran kavramının tanımı üzerinde çeşitlilikler söz konusudur. Kardaş\&Yalçın (2018), şükran olgusunun alan yazında şükran duyma, minnettar olma, teşekkür etme, kadirşinaslık, takdir etme, kıymet bilme, şükür, halinden memnun olma, hayatın ve olayların güzel yönlerini görme, sahip olunan olumlu yönlere odaklanma, memnuniyet, hayranlık ve teşekkür ifadesi gibi çeşitli kavramlar altında tartışıldığını vurgular. 
Şükran kavramını 'iyilik yapan', 'iyiliğin kendisi' ve 'iyilik yapılan' bağlamında ele alan Roberts (2004), “bireyin gördüğü bir yardım ve iyilik karşısında yardım eden kişiye yönelik minnet duygusu" tanımlamasında bulunmaktadır.

Diğer yandan, bazı araştırmacılar şükranı sadece bir duygu olarak değil, aynı zamanda bir kişisel özellik olarak betimler. Bu duruma dikkat çeken Chan (2010),bir duygu olarak ele alındığında şükranı "bir yarar sağlandığında oluşan teşekkür, merak ve takdir hissi" olarak tanımlarken; bir özellik olarak ele alındığında "kişinin şükran duyma durumunu deneyimleme yatkınlığı" olarak bir tanımlamada bulunmakta, iki durum arasında ayrıma gitmektedir.

Avrupa ve Amerika başta olmak üzere, yurt dişında şükran olgusunu konu alan birçok çalışma gerçekleştirilmiştir. Bu çalışmalar şükran olgusunun insan yaşamındaki pozitif etkilerini ortaya koymaktadır. Sonuçlar şükranın; pozitif duyguları ve iyimserliği yükselttiği, stres ve depresyona karşı koruyucu bir faktör olduğu, olumsuz yaşam olaylarının yeniden yorumlanması ve yılmazlık düzeyinin artmasına yardımcı olduğu, prososyal davranışları desteklediği, ilişki doyumuna katkıda bulunduğu, madde kullanımı, kendini suçlama, inkâr ve boş verme gibi sorunlar ile negatif bir ilişkiye sahip olduğu yönünde veriler sunmaktadır (Kardaş\&Yalçın,2018).

İçinde bulunulan kültürel çevreden bağımsız olarak, şükran durumunun oluşabilmesi için kişinin kendisine gösterilen yardımı, iyiliği ya da olumlu davranışı takdir duygusuyla karşılaması gerekir. Fakat şükran olgusunun kültüre özgü boyutları da söz konusudur (Fukuda, 2006). Örneğin, birçok toplumdan farklı olarak Japonya'da şükran duygusunun sadece 'memnuniyet' gibi pozitif duygularla ilintili olmadığı; kişide 'suçluluk' gibi -pozitif olarak değerlendirilmeyecek- duyguların oluşmasına da neden olduğu bilinmektedir (Naito et al.,2005; İkeda,2006). Bu bağlamda, Japon dili ve kültürü incelenmesi gereken bir örnek olarak karşımıza çıkar.

Bu çalışmada, Japonya'da yapılmış çeşitli alan çalışmaları tanıtılarak Japon insanının şükran olgusuna yönelik bakış açısı irdelenecektir. Japonların sıklıkla deneyimledikleri şükran durumları, söz konusu durumlarda hissettikleri duygular, bu duyguların dilsel yansımaları ve bunun arkasında yatan ahlak yargıları çalışmanın ana çerçevesini oluşturacaktır.

Son yıllarda ülkemizde gerçekleştirilen Japonoloji çalışmalarında artış yaşanmaktadır (Gençer, 2018). Bir ada ülkesi olan; coğrafi, dilsel ve kültürel bağlamda diğer ülkelerle karşılıklı etkileşimin sınırlı olduğu Japon toplumu özelinde gerçekleştirilecek bir değerlendirme, şükran olgusu üzerine ileride yapılacak çalışmalara farklı pencereden bir veri sunacaktır. 


\section{1. ŞÜKRAN DURUMLARI VE HISSEL DENEYIMLER}

İkeda (2006), bir Japon'un yaşam döngüsü içinde şükran duygusunu sıklıkla hissettiği figürler arasından 'anne' karakterinin önemine dikkat çekmekte; çalışmasında Japonya'da çocukluktan ilk gençlik yıllarına geçiş ile anne figürüne hissedilen şükran duygusundaki değişimleri irdelemektedir. Ortaokul, lise ve üniversitede eğitim gören beş yüz seksen beş öğrenci ile yapılan araştırmada, katılımcılardan annelerine duydukları şükran hissini yazılı olarak ifade etmeleri istenir. Elde edilen yantlar 'desteğinden ötürü mutluluk', 'büyüttüğü için minnet', 'dünyaya getirdiği için gönül borcu' ve 'verilen zahmetten ötürü üzüntü' olarak dört ana gruba ayrılmaktadır. Bunlardan 'verilen zahmetten ötürü üzüntü' dışındaki diğer üç madde, yaş faktöründen bağımsız olarak tüm gruplarda ortak olarak görülürken söz konusu madde ortaokul öğrencilerinde gözlemlenememiştir.

Bir Japon'un yaşam döngüsü içerisinde şükran duygusu hissettiği olgulardaki değişimi ortaya çıkarmayı amaçlayan İkeda (2015); onlu (on beş yaş üstü), yirmili, otuzlu, kırklı, ellili ve altmışlı yaş gruplarından toplam bin sekiz yüz katılımcı ile bir çalışma gerçekleştirmektedir. Çalışmada, önceki alan çalışmaları taranarak şükran duygusu uyandıran yirmi madde belirlenmiş, katılımclara her bir madde için gündelik hayatta ne sıklıkta şükran duygusu hissettikleri sorulmuştur. Elde edilen veriler; 'değişimsiz insan ilişkileri', 'değiş̧imli insan ilişkileri' ve 'soyut kavramlar' olarak üç ana grupta değerlendirilmektedir. Bunlardan 'değişimsiz insan ilişkileri' kategorisinde 'anne', 'baba' ve 'çalışma arkadaşları' yer almaktadır. Katılımcılar arasında anlamlı bir fark görülmemekte, bu kategoride yer alan kişilere karşı her yaş grubunca istikrarlı bir şekilde şükran hissi duyulmaktadır. Diğer yandan 'değişimli insan ilişkileri' kategorisi 'arkadaş', 'partner', 'büyük anne', 'büyük baba', 'öğretmen', 'çocuk', 'kardeş' ve 'ağabey'den meydana gelmektedir. Bu kişilere duyulan en yüksek ve en düşük şükran seviyesi yaşa göre farklılıklar göstermekte, İkeda (2015)'ya göre bu durum kişinin içinde bulunduğu yaşam döngüsüyle ilişki arz etmektedir. Örneğin, öğrenim yaşındaki bir Japon'un yaşamında 'arkadaş' ve 'öğretmen'in önemi diğer yaş gruplarına göre daha yüksek olduğundan bu durumun şükran hissetme sıklığına etki etmesi olağandır. Son olarak 'soyut kavramlar' kategorisinde ise 'doğa', 'sağlık' ve 'hayatın devamlılı̆̆ı' maddeleri yer almaktadır. Elli ve altmışlı yaş grubundaki katılımcılar diğer yaş gruplarına göre bu kategorideki olgulara daha sık şükran hissi deneyimlemektedir. Araştırmada, yaşam döngüsü içerisinde şükran duygusu uyandıran olguların somuttan soyuta doğru bir değişim gösterdiği vurgulamaktadır.

Diğer yandan Satake (2010), nesil farklılığına dikkat çekerek üniversite öğrencileri ile anne babalarının şükran duygusu hissettiği durumları karşılaştırır. Çalışmada üniversite öğrencisi yüz katılımcı ile anne babalarından son zamanlarda şükran duygusu hissettikleri 
üç olayı yazmaları istenir. Elde edilen yanıtlar içeriklerine göre 'yardım kaynaklı' ('cesaretlendirme', 'yardım',' tavsiye' vb.) ve 'doyum kaynaklı' ('sağlık', 'huzur',' hayat' vb.) olmak üzere iki ana grupta değerlendirilmektedir. Sonuçlar; öğrencilerin 'yardım kaynaklı' durumlarda, anne babalarının ise 'doyum kaynaklı' durumlarda daha sık şükran duygusu hissettiğini ortaya koymaktadır. Diğer yandan şükran duyulan kişilerin nitelikleri göz önüne alındığında, öğrencilerin 'arkadaş' ve 'öğretmen' den söz ederken, anne ve babalarının büyük oranda 'aile' olgusuna atıf yaptıkları görülmektedir.

Japonya'daki gündelik hayatta ilkokul ve üniversite öğrencilerinin sıklıkla deneyimledikleri şükran durumlarını araştıran Fujiwara et al., (2013) ve Kuranaga et al.,(2011), önemli veriler sunmaktadır. Fujiwara et al., (2013),ilkokul dördüncü sınıftan altıncı sınıfa kadar yüz yetmiş dokuz katılımcıyla yaptığı çalışmasında öğrencilerin deneyimlediği şükran durumlarını 'maddi destek' ('hediye alma', 'yemek hazırlama' vb.), 'manevi destek' ('övme', 'cesaretlendirme' vb.) ve ‘soyut durumlar'('kibar davranılma', 'yardım görme' vb.) başlıklarıyla üç grupta kategorize etmektedir.

Diğer yandan, Kuranaga et al.,(2011), dört yüz otuz dört üniversite öğrencisi ile yaptıkları çalışmalarında, üniversite öğrencilerinin günlük hayatta sıklıkla deneyimledikleri şükran durumları ve bu durumlarda meydana gelen duyguları irdeler. Çalışma sonucunda, Japon üniversite öğrencilerinin sıklıkla karşılaştıkları şükran durumları; 'yardım alma' (ör. İşi başaramayıp ağladığımda, arkadaşım beni dinleyerek destek oldu.), 'armağan alma' (ör. Doğum gününde çalıştığım yerden hediye aldım.), 'durumda olumlu değişiklik' (ör. Çok isteyerek aradığım kitabı sonunda buldum.), 'huzur' (ör. Tatil günü gözlerimi açtığımda hava çok güzeldi ve dışarıdan kuş cıvıltıları duyuluyordu.), 'başkalarına yük' (ör. Gözümde büyüdüğü için ertelediğim aile gezisi organizasyonunu annem yaptı.) başlıkları altında beş grupta kategorize edilmektedir. Çalışmada bu sınıflandırma yönteminin kapsayıcı bir nitelik taşıdığı, alan yazında geçen tüm şükran durumlarını bu beş kategoriden birine tasnif etmenin mümkün olduğu vurgulamaktadır. Aynı çalışmada, şükran durumlarında hissedilen duygular ' tatmin', 'üzüntü' ve 'rahatsızlık' ana başlıklarında kategorize edilmektedir. Bunlardan 'tatmin'; 'mutluluk', 'teşekkür', 'gönül rahatlı̆̆g' gibi olumlu duyguları içerirken, 'üzüntü' kategorisinde ise 'pişmanlık', 'utanma', 'suçluluk' gibi kişinin kendisini suçlaması sonucu oluşan duygular yer almaktadır. Diğer yandan 'rahatsızlık' kategorisi; 'sıkıntı', 'hoşnutsuzluk' gibi son derece olumsuz duyguları içermektedir. Kuranaga et al., (2011); 'rahatsızlık' kategorisindeki yanıtların sınırlı sayıda gözlemlendiğini; bu yanıtların temelinde, başkalarının yaşadığı rahatsızlık verici bir olayın kişi tarafından kendi başına gelmediği için şükranla karşılanmasının yattığını belirtmektedir. Bu bulgular; Japonya'da şükran durumlarında 'tatmin' ile 'üzüntü' duygularının sıklıkla yaşandığı; 'rahatsızlık' duygusunun ise bu bağlamda değerlendirilmeyeceği anlamına gelir. Bu 
sonuçlar,Japonya ve Tayland özelinde karşılaştırmalı çalışma yürüten Naito et al., (2005) ve Wangwan $(2004,2005)$ ile de örtüşür niteliktedir. Naito et al., (2005) ve Wangwan (2005), 'yardım görme' durumunda Japon üniversite öğrencilerinde meydana gelen duyguları 'pozitif duygular', 'borçluluk duygusu' ve 'negatif duygular' olarak üç grupta değerlendirmektedir. Söz konusu çalışmalarda olumlu sosyal davranışla ilişkilendirilen 'pozitif duygular' ile 'borçluluk duygusu' şükran durumundaki temel hisler olarak kabul edilirken, 'negatif duygular' kapsam dışı bırakılmıştır. Wangwan (2004), şükran durumunda meydana gelen 'pozitif duygular' ile 'borçluluk duygusu'nun iyilikte bulunan kişinin 'ödediği bedel', bu iyiliğin 'arzulanırlık derecesi' ve 'edinilen yarar' ile pozitif yönde bir ilgileşim içinde olduğunu belirtmektedir. Araştırma sonucuna göre; şükran durumunda hissedilen 'borçluluk duygusu' Japon üniversite öğrencilerince son derece güçlü hissedilmekte; bu durum onları iyiliğe karşılık vermeye ve olumlu sosyal davranışta bulunmaya sevk etmektedir.

\section{2. ŞÜKRAN-ÖZÜR İLIŞKISINININ JAPONCADAKİ YANSIMASI}

Yukarıdaki çalışmalardan anlaşılacağı üzere, şükran durumuyla karşılaşan bir Japon; pozitif duyguların yanı sıra 'suçluluk', 'pişmanlık' gibi negatif duyguları da birlikte hissetme eğilimi gösterir. Bu durum Japoncada da karşılık bulmakta, şükran durumlarında 'teşekkür ifadesi' ile 'özür ifadesi' birbirlerinin yerine ya da birlikte kullanılabilmektedir.

Japonca öğrenimine yönelik ders kitapları incelendiğinde, şükran durumlarında özür ifadesi ile teşekkür ifadesinin birlikte kullanıldığı örnek alıştırmalara sıklıkla rastlanılır:

1. A: İyi misiniz? Birlikte hastaneye gidelim mi?(Daijōbudesu ka. İşşoni byoin ni ikimashō ka.)

B: Özür dilerim. Teşekkür ederim. (Sumimasen. Arigatō gozaimasu.)

2. A: Zor olmalı. Yardım edelim mi? (Taihendesune. Tetsudaimashō ka.)

B: Özür dilerim. Teşekkür ederim. (Sumimasen. Arigatō gozaimasu.)

(Japan Foundation, 2014: 99)

Japonların şükran durumlarında özür ifadesini sıklıkla tercih etmesi, onları İngilizce konuşurken 'thank you' demeleri gereken bağlamda yanlışlıkla 'I am sorry' ifadesini kullanmalarına neden olur (Okamoto, 1992).

Japonca özelinde yürütülen çalışmalarda, şükran durumlarında teşekkür ve özür ifadesinin kullanımını etkileyecek faktörlere yönelik çok sayıda çalışma mevcuttur.

Sakuma (1983)'ya göre, şükran duygusunu oluşturan yapıda 'affedilme arzusu' göz ardı edilmemelidir. Bu durum 'özür' hissiyatı ile ortaklık gösterir. Bir Japon görmüş olduğu bir iyilik sonucunda 'af dileme' hissini güçlü hissediyorsa 'özür ifadesi'ni tercih edecektir. 
Diğer yandan, örneğin 'hediye alma' durumunda olduğu gibi 'mutluluk' hissi yoğun yaşanıyorsa 'teşekkür ifadesi'nin kullanılması beklenir. Sakuma (1983)'ya göre, kendisine yeşil çay ikram edilen bir Japon'un, hissettiği mutluluktan ötürü teşekkür etmesi ya da verdiği zahmet sebebiyle özür dilemesi bu bağlamda değerlendirilmelidir.

Şükran ile özür arasındaki ilişkiyi sistematikleştiren Miyake (1993), 'borçluluk' kavramı merkezli bir modelden bahseder. Miyake (1993)'ye göre, klyafeti konusunda iltifat alan bir kişiden bu durumdan hoşnut olması fakat borçluluk hissetmemesi beklenir. Böylesi durumlarda, teşekkür ifadesi kullanılacaktır. Diğer yandan kişi, yapılan iyiliğe karşı şükran duygusu ile birlikte bir borçluluk hissediyorsa, ağırlıklı hissettiği duyguya göre teşekkür ifadesi ve/veya özür ifadesini kullanabilir. Miyake (1993), şükran ve borçluluğun söz konusu olduğu durumlarda Avrupa kültüründe teşekkür ifadesinin, Japon kültüründe ise özür ifadesinin kolay tercih edildiğini vurgular. Japonların İngilizce konuşurken minnet göstergesi olarak yanlışlıkla 'I am sorry' ifadesini kullanması, araştırmacıya göre bu bağlamda değerlendirilmelidir.

Okamoto (1992), yüz dört üniversite öğrencisi ile yaptı̆̆ çalışmasında, Japonya'da karşı tarafa verilen zahmet ile özür ifadesi seçimi arasında bir ilgileşim olduğunu kanıtlar. Ayrıca çalışmada, kişiler arası sosyal mesafenin de özür ifadesi tercihinde bir etken olduğu tespit edilmiştir. Karşı tarafa verilen zahmetin benzer ağırlıkta olduğu durumlarda, iyilik gören kişi kendisine yakın gördüğü kişiye teşekkür ifadesi, uzak gördüğü kişiye ise özür ifadesi kullanma eğilimindedir.

Japoncada şükran durumlarında görülen teşekkür ve özür ifadelerinin kullanımını kategorize etmek amacıyla Okomato (2006:109), dört faktöre işaret eder (Aşağıda; dinleyici 'iyilik yapan kişi'yi, konuşucu 'iyilik gören kişi'yi ifade eder.) :

1.Dinleyicinin Vazifesi: Dinleyicinin eylemi mesleki vazife sınırları içerisindeyse konuşucu teşekkür ifadesi kullanır. Örneğin, servis yapan bir garsona müşterinin teşekkür ifadesi kullanması beklenir. Çünkü garsonun bu davranışı mesleki vazife kapsamında değerlendirilecektir.

2.Dinleyicinin Dostane His Sergilemesi: Dinleyici birincil amaç olarak dostane hislerini ifade etmeyi amaçlamaktaysa konuşucu teşekkür ifadesini daha kolay tercih edecektir. Buna örnek olarak 'hediye alma', 'iltifat', 'kutlama' gibi durumlar gösterilebilir.

3.Konuşucu ve Dinleyicinin İnsan İlişkileri: Dinleyici konuşucuya göre daha yaşlı ve /veya sosyal mesafe söz konusuysa, konuşucu özür ifadesini daha kolay tercih edecektir.

4.Sorumluluğun Kaynağı: Dinleyiciyi harekete geçiren olayda sorumluğun kaynağ1 konuşucudaysa, konuşucu özür ifadesini daha kolay tercih edecektir. Örneğin, unuttuğu cüzdanını arkasından koşarak getiren dinleyiciye karşı konuşucunun 
sorumluluk hissetmesi ve özür ifadesini tercih etmesi anlaşılır bir davranış

biçimidir.

Okomato (2006:109), yukarıdaki dört durumu 'zahmet' kavramı altında özetler. Buna göre, dinleyicinin yüksek statüde ve/veya sosyal olarak uzak olduğu, konuşucunun sorumluluk hissettiği durumlarda dinleyiciye zahmet verildiği algısı güçlü olacak ve özür ifadesi kolay tercih edilecektir. Diğer yandan, dinleyicinin düşük statüde ve/veya sosyal olarak yakın olduğu, bulunduğu eylem vazife sınırları içinde değerlendirildiği, dostane hisler sergileme amaçlandığı durumda dinleyiciye verilen zahmet algısı güç kaybedecek ve özür ifadesinin kullanım sıklığında düşüş yaşanacaktır.

\section{JAPON AHLAK DEĞERLERINNDEN ON VE GİRI}

Alan çalışmalarında 'af dileme arzusu', 'borçluluk', 'zahmet' gibi farklı kavramlar kullanılsa da, bütüncül olarak değerlendirdiğimizde iyilik gören bir Japon'un karşı tarafta neden olduğu 'yük'e karşı hassas davrandığı; bunun sonucunda 'suçluluk', 'pişmanlık', 'borçluluk' gibi duygular yaşadığı sonucuna varmaktayız. Bu durumu daha iyi analiz edebilmek için Japon ahlak yargılarından on ve giri kavramlarını irdelemek gerekir.

Japonca Kanji Sözlüğ̈̈'nde on ideogramı "iyilik, lütufkârlık, hoşgörü, minnettarlık" olarak; giri ideogramı ise "mükellefiyet, mecburiyet, vazife hissi, taahhüt" olarak açıklanmaktadır (Demirci, 1998).

Bu ahlak yargılarının sıradan bir Japon üzerindeki etkisi üzerine iki önemli antropolog, Benedict (1965) ve Lebra (2013)'nın saptamaları son derece değerlidir.

Benedict (1965), Japon kültürü üzerine yaptığı çı̆̆ır açıcı çalışması Krizantem ve Kılıç adlı kitabında on ve giri kavramlarını tanıtmak için dört bölüm ayırmıştır. Japonların yapılan iyiliğin geri ödenmesine verdiği önemi bu kavramlar ekseninde açılayan Benedict (1965); Japonların minnet ifadesi yerine özür ifadesi kullandığına dikkat çekmekte; özür ifadesi olarak kullanılan sumanai yapısının "bitmek, çözümlemek, geri ödemek" anlamına gelen sumu fiilinin olumsuz hâli olduğunu dile getirmektedir. Bir diğer deyişle, Japoncadaki özür ifadesinde 'borcun geri ödenmemişliği'ne vurgu yapıldığı görüşünü savunur.

Benedict (1965)'e göre, on kavramı bir insanın büyük küçük borçlarının hepsini içine alan 'mükellefiyetler' manasına gelir. Bu kavram; 'mükellefiyet', 'sadakat', 'iyilik', 'sevgi' gibi ifadelerle tercüme edilse de bu kelimelerin hiçbiri kavramı tam olarak karşılayamaz. Fakat hangi anlamda kullanılırsa kullanılsın on kavramı, insanın mümkün olduğu kadar tahammül edebileceği bir yükü, bir borçluluğu, bir mecburiyeti de içinde barındırır. Bir insanın on'u hatırlamasının karşılıksız sevginin bir ifadesi olabileceğini belirten Benedict (1965: 111), Japonya'da ilkokul kitaplarında ahlak derslerinde çocuklara okutulan 'On'u Unutma' adlı hikâyeyi örnek olarak gösterir: 
Hachi akıllı bir köpekti. Doğar doğmaz bir yabancı onu aldı ve evinde çocuğu gibi baktı. Dolayısıyla sağlığı düzelen hayvan, her sabah efendisi işine giderken tramvay durağına kadar ona refakat eder ve akşam olunca efendisinin eve gelme saatinde, tekrar onu karşılamak üzere, durağa koşardı. Zamanla efendisi öldü. Hachi ise her gün efendisini aramaya devam etti. Ayn durağa giderek tramvay geldiği zaman kalabalığın içinden efendisinin çıkıp çıkmadığını görmeye çalışırdı.

$\mathrm{Bu}$ şekilde günler ve aylar geçti. Bir sene, iki sene, üç sene hatta on sene geçtiği hâlde yaşlı Hachi, durakta efendisini arar vaziyette her gün görünmekteydi.

(Benedict, 1965: 111)

Diğer yandan, Lebra (2013), on kavramını "sağlanan yardım ve menfaat ile bu yolla üstlenilen borç ve yükümlülükleri birbirine bağlayan bir ilişkisel kavram” olarak tanımlamakta; on'u alan kişinin kendisinden beklendiği gibi, on'u verene karşı minnettarlık duyduğunu vurgulamaktadır. Yazara göre on kavramı derin bir minnettarlık ve suçluluk duygusu içerdiğinden Japon ahlak anlayışının temellerinden birini oluşturmakta, mümkün olan en kısa sürede kurtulmayı gerektiren bir yük olarak görülmektedir. Karşısındaki istemediği halde on'u 'satmaya' kalkan kişi kınanır. Japon kültüründe, kişinin kendi verdiği hediyeyi küçümsemenin altında bu neden yatar. Kişinin hediye verirken; "Bu o kadar basit bir hediye ki size vermekten utanç duyuyorum." benzeri ifadeler kullanmasındaki amaç karşı tarafın kendisini borçlu hissetmemesini sağlamaktır.

On ile benzerlik gösteren bir diğer kavram giridir. Benedict (1965), bu kavramı toplum içindeki 'fertler için giri' ve bir insanın 'ismi için giri' olarak iki kısma ayırır. Bunlardan ilki, bir insanın ödemekle mükellef olduğu on anlamına gelirken, ikincisi, kişi şerefinin herhangi bir töhmetle lekelenmesine mâni olma vazifesi anlamına gelir.

Lebra (2013) ise, giri kavramını; borçlunun kendi içinde hissettiği bir baskı olarak değerlendirir. Böyle bir baskı nedeniyle borçlu kendi davranışlarında alacaklıya bağlı olduğunu düşünür. Giri olgusu nedeniyle borçlu, borcunu ödemek için büyük çaba harcar. Ancak bunu içinden gelen minnettarlık duygusunu göstermekten ziyade borçtan kurtulup özgürlüğünü yeniden kazanmak için yapacaktır. Yazara göre; Japonya'da giri duygusunun dayanılmaz baskısı yüzünden, kimse on'u alan borçlu kişi konumunda olmak istemez.

\section{SONUÇ}

$\mathrm{Bu}$ çalışmada Japonya'da şükran olgusu üzerine yapılmış çalışmalar tanıtılarak, Japonların günlük hayatlarında sıklıkla deneyimledikleri şükran durumları, söz konusu durumlarda hissettikleri duygular, bu duyguların dilsel yansıması ve bunun arkasında yatan ahlak yargıları irdelenmiştir.

Öncelikle, Japonya'da şükran durumları ile yaşamsal döngü arasında bir etkileşimin olduğu anlaşılmaktadır. 'Anne', 'baba', 'çalışma arkadaşı' gibi karakterler her daim şükran 
duyulan kişiler olarak karşımıza çıkarken yaşlılıkla birlikte 'doğanın zenginliği', 'sağlık', 'hayatın devamlılığı' gibi soyut kavramların önem kazandığı görülmektedir. Sıklıkla şükran duyulan kişiler arasında öğrencilerin 'arkadaş' ve 'öğretmen'e, anne babalarının ise 'aile' olgusuna vurgu yapması bu döngü ile ilişkilidir.

Diğer yandan, Japonya'daki şükran durumlarını kategorize etmeyi amaçlayan çalışmalar incelendiğinde araştırmacıların farklı yaklaşımlarla farklı sınıflandırmalara gittikleri anlaşılmaktadır. Japonya'daki şükran durumlarını 'yardım alma', 'armağan alma', 'durumda olumlu değişiklik', 'huzur' ve 'başkalarına yük' başlıkları altında somutlaştıran Kuranaga et al.,(2011)'nın çalışması benzerlerinden ayrılmakta; söz konusu beş kategorinin alan çalışmalarında kullanılan diğer tüm şükran durumlarını sınıflandırmada yeterli olacağı iddiası çalışmaya önem kazandırmaktadır.

Japonların şükran durumlarında hissettiği duygular incelendiğinde, müteşekkirliğin yanı sıra 'suçluluk', 'üzüntü' gibi negatif duyguların da birlikte meydana geldiği anlaşılmaktadır. Karşı tarafa zahmet verildiği algısı bu tür negatif duyguların oluşumuna zemin hazırlamaktadır. Diğer yandan şükran durumunda 'suçluluk' duygusunun oluşabilmesi için kişinin belli bir sosyalleşme sürecinden geçmesi bir ön koşul olarak karşımıza çıkar. 'Anne' figürüne yönelik lise ve üniversite öğrencilerinin 'verdikleri zahmetten ötürü üzüntü’ hissederken ortaokul öğrencilerinde bu duyguya rastlanılmaması (İkeda, 2006), şükran durumlarında 'suçluluk' duygusunun oluşumunda 'empati' kurabilme gibi belli bir bilişsel seviyesinin önemine işaret etmektedir.

Japonya'da şükran durumlarında pozitif duyguların yanı sıra 'suçluluk' gibi negatif duyguların hissedilmesi dilsel anlamda da karşılık bulmaktadır. Şükran durumlarında teşekkür ifadesiyle özür ifadesinin birlikte kullanılmasına sıklıkla rastlanılır. Bu dili öğrenen bir yabancı için, iyilik gören kişinin kullandığı 'Sumimasen. Arigatō gozaimasu.' (Özür dilerim. Teşekkür ederim.') ifadeleri ilk bakışta çelişki gibi algılansa da, 'suçluluk' ile 'müteşekkirlik' duygusunu birlikte ifade etmesi açısından iki farklı hissiyatın dile yansıması olarak değerlendirilmelidir.

Japonya'da şükran durumlarında gözlemlenen 'suçluluk', 'pişmanlık', 'üzüntü' gibi negatif duygular toplumun ahlaki yargılarıyla yakından ilintilidir. On ve giri kavramlarından anlaşılacağı üzere, 'yapılan bir iyiliğin geri ödenmesi' iyilik gören bir Japon'da mükellefiyet duygusu meydana getirir. Japonların karşı tarafa verdikleri zahmet konusunda hassas davrandıkları düşünüldüğünde, pozitif psikoloji kapsamında değerlendirilen 'şükran' olgusunun Japon toplumunda aynı zamanda bir 'baskı unsuru' niteliği taşıması doğal karşılanmalıdır. Lebra' (2013: 67)'nın “acil bir durumda bile diğer insanlardan yardım istemek, onlara göre yük olma anlamına geliyorsa, Japonlar böyle bir yardımı kabul etmez." saptaması bu kapsamda değerlendirilmelidir. 
Japonya'daki şükran olgusunu 'iyilik yapan', 'iyiliğin kendisi' ve 'iyilik yapılan' bağlamında ele aldığımızda, 'iyilik yapılan' bir Japon'un kendisini 'borçlu' hissetmesi durumunda ruhsal bir yükle karşı karşıya kalacağı sonucuna ulaşmaktayız. Bu durumda 'iyilik yapan' kişinin eylemde bulunmadan önce söz konusu iyiliğin gerekliliğini ve arzulanılırlığını doğru hesaplaması büyük önem taşır. Aksi takdirde Japonya'da gereksiz yere yapılan bir iyilik istenilmeyen bir şükran durumuna sebebiyet verme riskini de birlikte taşıyacaktır.

\section{KAYNAKÇA}

Bartlett, M. Y., \& DeSteno, D. (2006). “Gratitude and Prosocial Behavior:Helping When İt Costs You",Psychological science, 17(4), s.319-325.

Benedict, R., (1965). Krizantem ve Kılıç,(Çev:T.Turgut), İstanbul: Türkiye İş Bankası Kültür Yayınları.

Chan, D. W. (2010). “Gratitude İntervention and Subjective Well-Being Among Chinese School Teachers İn Hong Kong" , Educational Psychology, 30(2), s.139-153.

Demirci, M. (1998). Japonca-Türkçe Sözlük, İstanbul: Japon Kültür ve Enformasyon Merkezi.

Fredrickson, B. L. (1998). “Cultivated Emotions: Parental Socialization of Positive Emotions and Self-Conscious Emotions",Psychological Inquiry, 9(4), s.279-281.

Fujiwara,T., Murakami,T., \& Nishimura,T. (2013). “Shōgakuseini Okeru Kansha Seiki Jōkyō to Sono Hyōmeinii Tsuiteno Tansakuteki Kenkyū", Tsukubadaigaku hattatsu rinshō shinrigaku kenky $\bar{u}, 24$, s.19-26.

Fukuda ,M. (2006). Kanjiru Jōdō Manabu Kanjō:Kanjōgaku Josetsu,Kyoto: Nakanishiya. Gençer,Z. (2018). “Kokoro(Gönül) ve Eylül Romanlarında K,Sensei ve Necib’in Ölümlerinin Durkheim'ın İntihar Teorisi Bağlamında Analizi”, İnternational Journal of Language's Education and Teaching, 6(2), s.454-470.

Ikeda,Y. (2006). "Seinenkini Okeru Hahaoyani Taisuru Kansha no Shinri Jōtai no Bunseki", Kyōiku shinri-gaku kenkyū, 54(4 ), s.487 - 497.

Ikeda,Y. (2015). “Kansha wo Kanjiru Taishōno Hattatsuteki Henka”,Wayōjoshidaigakukiyō, ,55,s. 65-75.

Japan Foundation (2014). Marugoto Nihonno Kotoba To Bunka Shokyū 1 (A 2) Rikai, Tokyo: Sanshūsha.

Kardaş, F., \& Yalçın, İ. (2018). “Şükran: Ruh Sağlığı Alanında Güncel Bir Kavram”, Psikiyatride Güncel Yaklaşımlar,10(1),s.1-18.

Kuranaga, H. \& Higuchi, M. (2011). “Kansha Seiki Jōkyōni Okeru Jōkyō Hyōka ga Kansha no Kanjō Taikenni Oyobosu Eikyō" ,Kanjō shinrigaku kenkyū,19 (1 ), s.19-27. 
Lebra, T. S.,(2013). Japonlar ve Davranış Biçimleri, (Çev: O. Baykara), İstanbul: Boğaziçi Üniversitesi Yayınevi.

Luthans, F. (2002). "Positive Organizational Behavior: Developing and Managing Psychological Strengths", Academy of Management Perspectives, 16(1), s.57-72.

McCullough, M. E., Kilpatrick, S. D., Emmons, R. A., \& Larson, D. B. (2001). “Is Gratitude a Moral Affect?", Psychological Bulletin, 127(2), s.249.

Miyake ,K. (1993). “Kanshano İmide Tsukawareru Wabi Hyōgenno Sentaku Mekanizumu", Tsukubadaigaku Ryūgakusei Sentā Nihongo Kyōiku Ronshū, 8,s.19-38.

Naito, T., Wangwan, J., \& Tani, M. (2005). “Gratitude İn University Students in Japan and Thailand", Journal of Cross-Cultural Psychology,36(2),s.247-263.

Okamoto,S. (2006). Kotoba no Shakai Shinrigaku ,Kiyoto:Nakanishiya.

Okamoto,S. (1992). “Kansha Hyōgen no Tsukaiwakeni Kanyo Suru Yōin(2): 'Arigatō Taipu' to 'Sumimasen Taipu' wa Dono Yōni Tsukaiwakerareruka”, Aichigakuin daigaku bungakubu kiyō, 22, s.35-44.

Roberts, R. C. (2004). "The Blessings of Gratitude", R. A. Emmons \& M. E. McCullough (Eds.), The Psychology of Gratitude , (s.58-78). New York, NY: Oxford University Press.

Sakuma, K. (1983). Kansha To Wabi Hanashikotobano Hyōgen ,Tokyo: Chikumashobo. Satake, S. (2004). “Hitowa Nanini Tsuite Kansha Shiteiruka: Daigakusei to Sono Oya ga İdaku Kansha no Naiyō to Aite" , Yamagata Hoken İryō Kenkyū,7,s.1-8.

Seligman, M. E.P. \& Csikszentmihalyi, M. (2000). "Positive Psychology: An Introduction" American Psychological Association,55,s.5-14.

TDK (1998), Türkçe Sözlük. Ankara: Türk Dil Kurumu.

Wangwan, J. (2004). “Nihon to Tai no Daigakuseini Okeru Kansha Kokoro no Hikaku Kenkyū(1)" ,nihon Dōtokusei Shinrigaku Kenkyū,18, s.8-14.

Wangwan, J. (2004). “Nihon to Tai no Daigakuseini Okeru Kansha Kokoro no Hikaku Kenkyū (2)". Nihon Dōtokusei Shinrigaku Kenkȳ̄,19,s. 1-12. 


\section{BATI EDEBIYATINDA AKIMLAR}

editör

OKTAY YIVLi

HATICE FIRAT YASEMIN MUMCU

OKTAY YIVLI

OĞUZHAN KARABURGU

BERNA AKYÜZ SIZGEN

NILÜFER ILHAN
ÜMMÜHAN TOPÇU

SEFA YÜCE

HANIFI ASLAN

METIN AKYÜZ

MEHMET SÜMER

YAKUP ÖZTÜRK
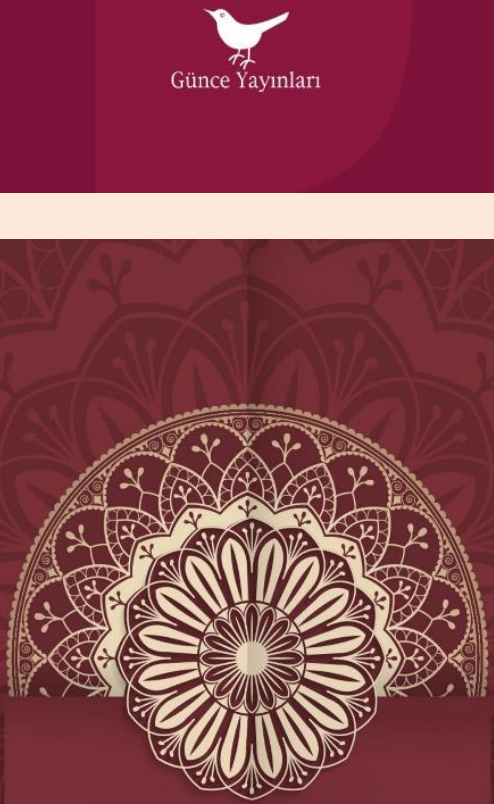

PROF. DR. ÖNDER GÖÇGÜN

$$
\begin{gathered}
\text { Türk } \\
\text { Tasavvuf } \\
\text { Siiri }
\end{gathered}
$$

AÇIKLAMALI VE YORUMLU ÖRNEKLERLE

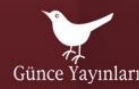

